\title{
THE LOVE THAT FRIGHTENS. CLINICAL-PEDAGOGICAL REFLECTIONS
}

\author{
Maria Grazia Riva \\ University of Milan-Bicocca, Italy
}

\section{Love in life and education}

The experience of love is common to all human beings, of all ages, social classes and geographical origins (Bettetini, 2012; Passerini, 2008). Contemporary society has typically dragged love out of the intimate sphere, partly as a result of technological advances in the mass communication media, especially Internet. The media constantly dwell on the themes of love and sex, honing in on people's love lives and making gossip about them a global affair, exposing the most intimate details of the love affairs of the famous and not so famous, and shamelessly flaunting nudity. TV programs exhibit the private joys and sufferings of romantic partners for the entertainment of the general public, while soap operas keep millions of people glued to the screen, fascinated by the amorous intrigues of the characters (Mitchell, 2002). Contents such as these tap into the deep core emotions of all human beings, an outcome which is sometimes manipulated to suit the dominant understanding of the laws of market (Russell Hochschild, 2012). However, love remains little understood and developed at both the individual and the social level, not so much in terms of moral judgments, as in terms of knowing how to manage and relate to it (Irigaray, 2002). Educational and formative processes are particularly liable to encounter the dimension of love, given that by their nature they place adults in life contexts with children, teenagers, youths, other adults and elderly people (Riva, 2004). Educational processes enter into the "world of life" with their educational intentionality - sometimes conscious and sometimes less so - that is to say, with their "world of education": the two worlds then interact, are mixed together, fused and confused. The world of life consists on the one hand of a social, institutional and organizational world, with its norms, procedures, rules, actions, values and cultures, and on the other of the essential microcosm of each individual subject, populated by deep emotions, aspirations, needs, fears and unresolved childhood issues (Mortari, 2006).

The educational services provided by society - such as community centres, daycare centres for teenagers, elderly people and the disabled, communities for young offenders, residential communities for minors, people with disabilities, psychiatric patients, drug addicts, alcoholics, homes for single mothers and children or for women abuse victims, etc. - come to the encounter with the world of life with their pedagogical aims, their educational intentionality and their educational methods and tools (Villa, 2008). These services employ helpers 
from a range of professional backgrounds to fulfil their primary duty, that of providing care and assistance to, and promoting the wellbeing and growth of, the subjects for whom they have "taken responsibility". Thus professional teams are created that may be made up of educators, psychologists, doctors, psychiatrists and social workers, or of educators only. The key issue here is that all of these careers bring to the team their own particular pedagogical model and educational style, their own views on a range of educational issues, and their own mentality, which is a function of both their personal family and educational experiences and their sociocultural background. When educators carry out intentional educational actions, they inevitably imbue them with their own culture and values, and their own specific perspective on education. Each educator has his or her own idea of what is right and what is wrong in educational terms, what one must do and what one must not do, what is to be rewarded and what to be punished. It is therefore critical to identify and analyze how the various professional helpers intervene through their own concrete practices to orient, channel, judge and model their clients' behaviors. This is the background against which we will examine the issue of love in educational processes, drawing on a specific case from real-life educational practice.

\section{The case study}

The context in which the case was observed was an educational community for adolescents, located on the outskirts of a large Northern Italian city. The community was founded about 15 years ago by a religious association, and the management was subsequently given over to a large and well-known cooperative in the social services sector. The coordinator of the community had a complex personal history: he had been a political activist during the 1970s. He subsequently encountered people who helped him rethink his life story and construct a new career for himself within the educational sector. He had therefore founded this community for adolescents which he managed together with a team of male and female educators, mostly aged between 30 and 40, with the exception of one or two older staff members. Given that the university research unit that I coordinate was conducting a study on evaluation models and procedure in educational services for minors, my colleagues and I visited the community on numerous occasions, carrying out a range of activities interviews, focus group discussions, collection of institutional and individual narratives, observation - in the course of our field research. During one of our sessions, the coordinator and team of educators told us about how they approach the issue of love in education (or rather one of the possible manifestations of love). They recounted having wanted at all costs a mixed (male and female) community of adolescents and having battled with the relevant authorities to gain approval for this formula. They had then constructed a well-defined 
protocol that involved giving new entrants to the community a talking to on arrival. In the course of their first encounter with the newly-arrived teenager, they explicitly addressed the issue of love in adolescence along the lines of: "You all have a lot of issues, each of you has a difficult background of your own so please don't fall in love because if you do you'll have the other person's problems on top of your own, and it will be a disaster. So, be good and don't fall in love with any of the boys/girls in the community, and everything will work out well". The educators went on to tell us, that the previous year, a boy and girl had not heeded their advice and had fallen in love with one another, and that this had given rise to a critical incident. At first the relationship between the two adolescents had gone smoothly, but then they had quarreled over "something really silly, and I mean really silly". The boy had gone to a disco with another girl, angering his girlfriend. The pair stopped talking to one another and this had created a dark and troubled atmosphere in the house. At that point, the educators called in the boy and decided to expel him from the community, thus restoring the peace (sic!).

\section{Clinical-pedagogical reflections}

This account presents a situation that was managed in a highly ambiguous manner by the community's team of careers, and educational interventions that generated what Gregory Bateson (1956) has termed 'double binds'. Contradictory messages were simultaneously sent to the clients. On the one hand the staff had held out to set up a mixed male-female community; on the other hand they wished to prevent the normal energy flowing between the sexes that attracts males to females and vice versa. The educators deliberately asked the teenagers entering the community not to fall in love, apparently failing to realize that falling in love is not something that can be voluntarily controlled. Equally paradoxical was their attempt to order adolescents not to fall in love, given that adolescence is the age par excellence in which individuals open up to the world outside the family, shifting the major emotional investments that they had previously reserved for their families to the external context. As is well known, preadolescence coincides with puberty, the development of the secondary sexual characteristics and of the ability to procreate (Vegetti Finzi, 2000; Waddell, 2002). According to the theories of psychoanalysis, in parallel with the biological development of the body, at the psychological level on coming out of the so-called latency phase adolescents go through a reedition of the Oedipus complex. Specifically, Freud maintained that the Oedipus complex first appears at around the age of 4-5 years, bringing to the fore the desire to possess the opposite-sex parent and competition with the same-sex parent. This complex and emotionally demanding phase is then followed by a period of relative calm corresponding with the primary school years, during which children make space 
inside of themselves and concentrate on aspects related to the outside world, such as learning and socialization. In early adolescence there is a reawakening of the Oedipus complex stimulated by the endogenous biological development underway, with its related sexual and affective desires, which can now be potentially put into practice. Given that incest is a strong taboo for our society, adolescents are led to direct their sexual and amorous needs and desires outside of the family context. Therefore, in this phase friendship and love play a vital role in promoting teenagers' psychophysical growth and development. Early adolescent love should be encouraged and supported, because it provides a channel - deemed appropriate by society - for the imposing force of teenagers' affective and sexual libido. If adolescents did not have the opportunity to channel their inner world of tempestuous emotions towards an external reference point, they would be forced to maintain a high level of affective investment in their family of origin, leading to serious psychological confusion.

In the latter scenario, the developmental course of adolescence would be obscured by a symbiosis with parents and siblings that would impede individuation of the self as an independent subject. Those who remain trapped in a symbiotic relationship with their families cannot go through the process that leads from absolute dependence, through relative independence, to the stage labeled by Winnicott as "towards independence". These adolescents are therefore prevented from undertaking the process of separation from their family of origin, a process which - differently to in childhood - has now become an imperative if they are to imagine, experience and construct their own future adult lives. Thus, adolescent love plays a key role for several reasons: the most important of these is that it provides a platform from which teenagers can embark on this critical separation process. Love also helps adolescents to cope with the changes in their own bodies, which frequently occur suddenly and tumultuously. They no longer recognize their own bodies, which are becoming different to the childish bodies to which they were accustomed, and this frightens them, making them feel lost and insecure. They have the sensation that their body-psyche is shedding its old childish skin and is taking on a new skin, but given that they have never had this experience before it is difficult for them to understand what is going on. Sometimes the physical changes in the body can give rise to strong feelings of fragmentation of parts of the self, including unexplainable feelings of death, depression and despair. Therefore, adolescents have a strong need of their peer group, so as not to feel that they are the only ones going through this transformation. They experience the need to share tastes, dress, behaviors, vocabularies and myths with the rest of the group, because a uniformity of preferences and attitudes makes them feel that there is something solid that they can depend on (Maggiolini, Charmet, 2003).

Requited adolescent love provides the teenager with a sense of self-acceptance, a sense of being lovable and pleasant to others, which in turn promotes a sense 
of self-esteem and of being able to manage relationships with the opposite sex, as his or her own mother and father do and as society demands. Love enables adolescents to feel confirmed, reassured and comforted and to verify that their own body, although it has changed, is still lovable, and that the lost childish parts have been replaced by new parts that are healthy, beautiful and good. This is also a key protection factor against the sense of fragmentation of the self, due to the loss of the childish body and psychological parts. Thus love plays a role in integrating the parts of self. Naturally, in addition to the support of their peer group and romantic partner, adolescents also need help from adults, in particular from educators, whether these are family members or professional helpers, both in the broader social context and in that of social and educational services. In the case of the residential community for minors, the situation is even more critical and delicate. The adolescents in this setting arrive there already in a state of crisis, often with a history of deprivation and abandonment on the part of their families. Their need to find sources of affective support, both amongst their peers and amongst the adult educators, is therefore all the greater (Kaneklin, 2003).

Clearly, these adolescents cannot but experience love in a way that is problematic, being compromised by their desperate but ambivalent need to form affective ties but at the same time to reject them. Those whose experience of the phase of affective dependence - an inevitable part of childhood - has been marked by neglect, abuse, violence and lack of affection, as they grow up will naturally come to desire affection just as strongly as they fear and run away from it. This ambivalence comes to the fore in adolescence, leading the teenagers to dip in and out of the affective relationships that they desire yet fear, both with their romantic partner and with their educators. Certain adolescent forms of acting out - such as forming an affective tie and then distancing oneself from it, seeking out serial romantic partners, breaking off relationships suddenly and without explanation, behaving contemptuously towards the affective relationship or towards the romantic partner themselves - may be connected to difficulty in sticking with a relationship that is desired but at the same time gives rise to anxiety and the fear of being abandoned or abused yet again. On the other hand, frequent changes of romantic partner may also be a normal adolescent behaviour. Adolescent love does not signify a pondered choice of partner but the need to explore the world outside the family, in order to get away from the specter of incest and to be confirmed as lovable people (Riva, 2012).

Educators working with this age group must therefore be aware of these complex psychological dynamics (Austin, 2003; Jeammet, 2008), which are part of normal adolescent development but are more pronounced in problem teenagers. Educators who have not received specific training in these developmental dynamics, or who have unresolved issues of their own - perhaps similar to those of the adolescents, which they have carried with them 
throughout their life stories - will inevitably encounter difficulty in managing educational processes with adolescents. The teenagers act as mirrors for the adults, reflecting stages of development that the adults thought they had long since gotten over and left behind (Barone, 2009). The educators are therefore strongly stimulated to confront their own outstanding personal issues, a process which may provoke feelings of disorientation, stress, insecurity and intense suffering. Furthermore, as emphasized at the outset of this paper, they bring their own educational models and peculiar mentality to their professional work as educators. If they have not had the opportunity to work on themselves, through a self-formative process, they will not realize that they are arbitrarily introducing entirely personal elements into their educational action. Frequently unbeknownst to themselves, they pass off as valid in the absolute sense, aspects of their own weltanschauung, of their own idiosyncratic world view. This vision of the world has been influenced by educators' personal life histories, by their cultural backgrounds, by the educational models that they experienced in their families, by the dominant mentality in their social context, and finally, by the way in which they have processed over their lifetimes the good and the bad in their own life stories and educational histories. Over time, cognitive elements such as representations, images, categorizations and systems of meanings - have combined with affective elements - including perceptions, sensations, emotions, feelings - in an inextricable interweaving of meanings that accompanies their individual experience and life events. The way in which professional helpers have emotionally experienced their own educational experiences from birth through their growth to maturity leads them to interpret the present through the selective filter of these emotive cognitions that are determined by their own particular life stories (Riva, 2011). When they encounter adolescents, who strongly draw them into contemplating the key questions of existence - love, sex, the meaning of life, death, corporeity, social rules and norms - educators are moved to deploy what is know as "pedagogical transfer", that is to say, they reproduce in the "here and now" what they themselves experienced in the past. The amorous moves of adolescents often bring into play educators' relationships with their own amorous education, which may have been complex and problematic in its own right. The challenges of romantic relationships are an essential part of the dimension of love, precisely on account of the complex set of social and personal factors that are at stake - a complexity that is often underestimated. This case provides a good example of pedagogical transfer as outlined above, that is of how we tend to adopt in the present the cultural and educational models that we grew up with (Fabbri, 2012). The educators apply an authoritarian model, with the addition of moralistic and judgemental elements, according to which falling in love is considered to be wrong, adolescents are not meant to fall in love with one another, love is a waste of time and a passing whim, adolescents need to be educated using a model that requires them to 
conform without argument to the models defined by the adults, that human beings are passive and without reactivity. They therefore implicitly expect that the reeducation of their clients will follow a model of change that is almost automatic, linear and faithful to the stimulus-response sequence, in terms of instruction-execution of the adult's request. It goes without saying that such a model of change is destined to fail miserably as the case described illustrates.

\section{Conclusions}

Love is frightening and educators, both at the individual level and as members of a team, are not always ready to deal with it. Educators fear love because it overturns their educational projects, forcing them to rethink the assumptions on which these projects are based and to question the validity of their methods and instruments. It upends the ready-to-go professional tool kit that the educators have partly learned during their initial and in-service training, partly developed on the basis of their practical experience and partly drawn from their personal pedagogical model as experienced in the family. Love goes outside fixed models, and this is even more so in the case of adolescents on account of the phase of biological development that they are going through: the advent of puberty, with its related bodily, cognitive and psychic changes. Educators require ongoing training, consultancy and supervision to help them reflect both on the specific nature of the problems that they encounter in their day to day educational practice and on the subjective dimension of their work (Graham, 2004; Bainbridge, West, 2012). If they do not develop their awareness of the latter aspect, they are likely to inadvertently project it onto their clients, forcing them into situations that are ambiguous, difficult to manage and, above all, unfair. Professional training (Riva, 2004; Blandino, 2009; Iori, 2010; Contini, 2001), both at the induction phase and in-service can play a key role in helping educators to gain awareness of their own stereotypes and judgments, and of their own beliefs about the different spheres of life and education. It is also critical to raise awareness, both amongst the general public and amongst social policymakers, of the need to invest resources and thought in adult training in order to impact in turn on the wellbeing of children and youth, and therefore of society as a whole.

\section{Bibliography}

1. Austin, W. (2003). The Adolescent's Experience of Amour. University of Michigan: Peter Lang

2. Bainbridge, A., West, L. (2012). Minding a gap. Psychoanalysis and Education. London: Karnac

3. Barone, P. (2009). Pedagogia dell'adolescenza. Milano: Guerini

4. Bateson, G., Jackson, D.D., Haley, J., Weakland, J. (1956). Toward a theory of schizophrenia. Behavioral Science, 1 (4):251 
5. Berto F., Scalari P. (2011). Mal d'amore. Relazioni familiari tra confusioni sentimentali e criticità educative. Molfetta: La Meridiana

6. Bettetini, M. (2012). Quattro modi dell'amore. Roma-Bari:Laterza

7. Blandino, G. (2009). Psicologia come funzione della mente, Paradigmi psicodinamici per le professioni di aiuto. Torino: UTET

8. Bowlby, J. (1979). The making and breaking of affectional bonds. London: Tavistock

9. Contini, M. (2001). Per una pedagogia delle emozioni. Firenze: La Nuova Italia

10. Fabbri, M. (2012). Il transfert, il dono, la cura: giochi di proiezione nell'esperienza educativa, Milano: Angeli

11. Foucault, M. (1975). Surveiller et punir : Naissance de la prison, Paris: Gallimard

12. Freud, A. (1958). Adolescence. The Psychoanalytic Study of the Child, 13, 255-278

13. Graham, P. (2004). The End of Adolescence: Exposing the Myths About the Teenage Years. London: Karnac

14. Harris, R., Rendall, S., Nashat, S. (2011). Engaging with Complexity: Child and Adolescent Mental Health and Education. London: Karnac

15. Iori, V. (2010). Il sapere dei sentimenti. Milano: Angeli

16. Irigaray, L. (2002). The way of Love. New York: Continuum

17. P.Jeammet, P. (2008). Pour nos ados, soyons adultes, Paris: Odile Jacob

18. Kaneklin, C., Orsenigo, A. (2003). Il lavoro di comunità. Roma: Carocci

19. Levesque, R. (2002). Dangerous Adolescents, Model Adolescents: Shaping the Role and Promise of Education. London: Karnac

20. Lopez, D. (1987). La via nella selva. Milano:Cortina

21. Maggiolini, A., Charmet, G. (2003). Manuale di psicologia dell'adolescenza. Milano:Angeli

22. Massa, R. (1993). La clinica della formazione. Milano: Angeli

23. Miller, A. (2007). La persecuzione del bambino. Le radici della violenza, Torino: Bollati Boringhieri

24. Mitchell, S. (2002). Can Love Last? The Fate of Romance Over Time. New York: Norton

25. Moore, S., Rosenthal, D. (2006). Sexuality in Adolescence: Current Trends. London: Karnac

26. Mortari, L. (2006). La pratica dell'aver cura. Milano:Bruno Mondadori

27. Palmieri, C. (2012). Crisi sociale e disagio educativo. Milano:Angeli

28. Passerini, L. (2008). Storie d'amore e d'Europa. Napoli-Roma:L'Ancora

29. Riva, M.G. (2004). Il lavoro pedagogico. Milano:Guerini

30. Riva, M.G. (2012). Il primo amore: un'esperienza costante dell'esistenza, in F. Borruso, L. Cantatore, Primo amore e progetto di vita. Frammenti di educazione sentimentale in Europa fra '700 e '900. Milano: Guerini

31. Riva, M.G. (2005). La passione in mezzo a noi. Breve saggio di 'pedagogia erotica'. ADULTITÀ, vol. 21, p. 85-96, ISSN: 2239-5288

32. Riva, M.G. (2011). L'educazione sentimentale: tra disorientamento degli adulti e bisogni dei giovani. In: Spadafora G; Corsi M. Progetto generazioni: i giovani, l'educazione, il mondo. p. 55-66, Roma:Tecnodid

33. Russell Hochschild, A. (2012). The outsourced Self. New York:Henry Holt and Company

34. Vegetti Finzi, S., Battistin A.M. (2000). L'età incerta. Milano: Mondadori

35. Waddell, M. (2002). Inside lives Psychoanalysis and the Growth of the Personality. London: Karnac

36. Winnicott, D.W. (1965). Adolescence: struggling through the doldrums. In The family and individual development (pp. 145-155). London: Tavistock. 


\begin{tabular}{|l|l|}
\hline Maria Grazia Riva & Department of Human Sciences for \\
& Education, University of Milan-Bicocca \\
& Piazza dell'Ateneo Nuovo, 1 \\
& 20144 Milan, Italy \\
& Email: mariagrazia.riva@unimib.it \\
& Tel. +39.3485628700 \\
\hline
\end{tabular}

